\title{
Acute inflammatory bowel disease in childhood: a new disease?
}

\author{
P. D. MANUEL, ANNE KILBY*, D. CANDY, J. A. WALKER-SMITH, AND J. T. HARRIES \\ From the Queen Elizabeth Hospital for Children, and the Hospital for Sick Children, London
}

SUMMARY Three children aged between 7 and 11 years, after an acute onset of diarrhoea and vomiting, developed protracted diarrhoea and severe loss of weight. None had been abroad. No significant aetiological agent was found. There was evidence of acute inflammatory disease on proximal small intestinal biopsy, and some evidence of more widespread gut involvementof the rectum in Cases 1 and 2, and the terminal ileum in Cases 2 and 3. The disease resolved spontaneously and without relapse.

Acute diarrhoea and vomiting in the developed world is usually a self-limiting illness of short duration in children beyond infancy. This report concerns 3 older children in whom illness started with the acute onset of diarrhoea and vomiting that did not resolve as expected, and in whom evidence of acute inflammation was found in both the small and large intestine. Its purpose is to draw attention to this disease and to describe the spontaneous resolution which occurred despite the severe and prolonged nature of the illness.

\section{Case reports}

Case 1. A 6-year-old boy was admitted with a 3-week history of diarrhoea, vomiting, and a weight loss of $5 \mathrm{~kg}$. He had no abdominal pain, had not travelled abroad, or been in contact with diarrhoeal illness. Lomotil was the only drug administered before admission to hospital.

On examination he was $5 \%$ dehydrated with a distended, non-tender abdomen. His height was on the 90th centile, his weight, at $21 \mathrm{~kg}$, had fallen from the 97 th to the 25th centile. Haemoglobin $(\mathrm{Hb})$, white blood count (WBC), erythrocyte sedimentation rate (ESR), immunoglobulins, C14 glycocholate breath test, urinary indican, normal. Serum iron $7 \cdot 5$ $\mu \mathrm{mol} / 1(41 \cdot 9 \mu \mathrm{g} / 100 \mathrm{ml})$ range 13.6-28.2 (76.0 $157.5 \mu \mathrm{g} / 100 \mathrm{ml})$, total iron binding capacity (TIBC) $47 \cdot 4 \mu \mathrm{mol} / 1(265 \mu \mathrm{g} / 100 \mathrm{ml})$ range $44 \cdot 6-69 \cdot 3$ (249-387 $\mu \mathrm{g} / 100 \mathrm{ml}$ ), saturation $15 \cdot 9 \%$ range

Received 20 December 1977

*Present address: University College Hospital, Gower Street, London, WCI
$25 \cdot 5-56 \cdot 2 \%$; serum folate $5 \mu \mathrm{g} / 1$ (low $\dagger$ ); plasma carotenoid $0.67 \mu \mathrm{mol} / 1 \quad(36 \mu \mathrm{g} / 100 \mathrm{ml})$ range 1.9-2.8 (102-150 $\mu \mathrm{g} / 100 \mathrm{ml})$. Stool, Escerichia coli 055 on one occasion, scanty cysts of Giardia lamblia on one occasion. Barium meal and follow-through, dilated loops of small intestine with mucosal thickening, otherwise normal. Small intestinal biopsy (duodenojejunal flexure), severe partial villous atrophy (PVA) with neutrophil and plasma cell infiltrate of the lamina propria, intraepithelial lymphocytes 29/100 epithelial cells (normal 6-32), disaccharidases normal. Duodenal juice, no Giardia seen, total lumen count $10^{4}-10^{5}$ organisms/ $\mathrm{ml}$ juice, Klebsiella present at $10^{3}-10^{4}$ organisms $/ \mathrm{ml}$ juice, bacteroides $4 \times 10^{2}$, proprionibacterium $1 \times 10^{3}$. At sigmoidoscopy the rectal mucosa was red and oedematous.

The patient's symptoms abated without treatment afier 3 weeks in hospital. Nine months later he was asymptomatic and his weight at $26 \mathrm{~kg}$ had returned to the 90th centile. Investigation at that time showed: serum iron $9 \cdot 1 \mu \mathrm{mol} / 1$ (51 $\mu \mathrm{g} / 100 \mathrm{ml})$, TIBC 63 $\mu \mathrm{mol} / 1(352 \mu \mathrm{g} / 100 \mathrm{ml})$, saturation $14 \cdot 5 \%$, serum folate $3.5 \mu \mathrm{g} / \mathrm{l}$ (low $\dagger$ ), red cell folate $857 \mu \mathrm{g} / \mathrm{l}$ (high $\dagger$ ); small intestinal biopsy (2nd part duodenum), normal histology, intraepithelial lymphocytes $20 / 100$ epithelial cells, disaccharidases normal; duodenal juice, no Giardia seen.

Two years after initial presentation he was well, his height being on the 90th centile, his weight at

Measurements of serum and red cell folate were performed at two laboratories:

†Department of Haematology, Great Ormond Street Children's Hospital. Normal ranges : serum folate 5.9-21 $\mu \mathrm{g} / 1$; red cell folate $150-650 \mu \mathrm{g} / \mathrm{l}$. 
$31 \mathrm{~kg}$ lying between the 90th and 97th centiles. Serum iron, vitamin B12, and folate; red cell folate, all normal. He has remained well since.

Case 2. An 11-year-old previously healthy boy presented with a 4-week history of diarrhoea and vomiting of sudden onset. He had lost $10 \mathrm{~kg}$ in weight but had no abdominal pain. He had not been abroad or had any contact with diarrhoeal illness. He had received no antibiotic treatment. On examination he looked very thin but was otherwise well, with his height on the 97th and his weight at $38.5 \mathrm{~kg}$ on the 50 th centile. $\mathrm{Hb}$, serum vitamin B12, stool culture, parasites negative. Examination of stools by electron microscopy revealed no virus particles; serological tests and stool culture for viruses were also negative. IgG $8 \cdot 13 \mathrm{~g} / 1$ (normal $3 \cdot 70-15 \cdot 30)$, IgA $1 \cdot 53 \mathrm{~g} / 1(0 \cdot 71-2 \cdot 56)$, IgM $0 \cdot 22$ $\mathrm{g} / 1(0.44-1.95) ;$ WBC $16.5 \times 10^{\circ} / 1(16.5 \times$ $10^{3} / \mathrm{mm}^{3}$ ) (neutrophils $79 \%$ with toxic granulation, lymphocytes $20 \%$ ); ESR $18 \mathrm{~mm} / 1 \mathrm{~h}$; serum iron $10 \mu \mathrm{mol} / 1(56 \mu \mathrm{g} / 100 \mathrm{ml}$ ), folate $2.7 \mu \mathrm{g} / 1$ (low + ), red cell folate $109 \mu \mathrm{g} / 1$ (low $)^{\dagger}$ ). Barium meal and follow-through, rapid transit (barium had reached terminal ileum by 20 minutes), dilated loops of small intestine, narrowed terminal ileum. Small intestinal biopsy (4th part duodenum), severe PVA with neutrophil and plasma cell infiltrate of lamina propria, intraepithelial lymphocytes $32 / 100$ epithelial cells, lactase $0 \mu \mathrm{mol} / \mathrm{min}$ per $\mathrm{g}(2 \cdot 0-16 \cdot 2)$, maltase $2 \cdot 2(14 \cdot 6-77 \cdot 0)$, sucrase $0 \cdot 3(3 \cdot 1-20 \cdot 2)$. Duodenal juice, Giardia not seen. Barium enema, normal colon and terminal ileum. Sigmoidoscopy, reddened, oedematous rectal mucosa. Rectal biopsy, intact epithelium, moderate patchy neutrophil infiltrate of lamina propria.

Symptoms subsided without treatment during the period of investigation. Three months later he was asymptomatic and weighed $47.6 \mathrm{~kg}$ (90th centile). Investigation showed serum vitamin B12 normal. Small intestinal biopsy (4th part duodenum), normal histology, lymphocytes $31 / 100$ epithelial cells, disaccharidases normal. Serum folate $3 \cdot 7 \mu \mathrm{g} / \mathrm{l}$ (low + ), red cell folate $146 \mu \mathrm{g} / \mathrm{l}\left(\mathrm{low}_{+}^{+}\right)$. He has remained well for one year. his height on the 97th centile and his weight at $58 \mathrm{~kg}$ between the 90th and 97th centiles. Serum folate, red cell folate, and immunoglobulins have returned to normal.

Case 3. An 11-year-old boy presented with a similar history. His illness had started 3 months previously, soon after treatment for threadworms, with diarrhoea, vomiting, and left lower quadrant abdominal

$\ddagger$ Haematology Department, St Bartholomew's Hospital. Normal ranges: serum folate $4-18 \mu \mathrm{g} / \mathrm{l}$; red cell folate $160-900 \mu \mathrm{g} / \mathrm{l}$. pain. He had lost approximately $6 \mathrm{~kg}$ in weight during this period. He had had no contact with diarrhoeal illness, nor had he travelled abroad. Height was on the 90th centile, his weight at $32.5 \mathrm{~kg}$ on the 25th, he looked unwell, but no abnormal cigns were detected. Hb, WBC, ESR, serum iron, vitamin B12, immunoglobulins, plasma protein, serum calcium, magnesium, phosphate, glucose, alkaline phosphatase, aspartate transaminase, alanine transaminase normal; acute phase titres for CMV, Paul-Bunnell, Yersinia enterocolitica, and pseudotuberculosis negative. Stool, culture, parasites negative. Serum folate $3 \cdot 8 \mu \mathrm{g} / \mathrm{l}$ (low $\dagger$ ). Barium meal and follow-through, dilated loops of jejunum with transverse banding, otherwise normal. Small intestinal biopsy, severe PVA with increased inflammatory cell infiltrate of the lamina propria; lymphocytes $34 / 100$ epithelial cells. Barium enema, normal large bowel, the terminal ileum was abnormal showing flattening of the mucosal pattern. Sigmoidoscopy, normal rectal mucosa. Rectal biopsy, normal. Symptoms abated without treatment while these investigations were being performed.

When seen in outpatients 2 months later he was well and weighed $39 \mathrm{~kg}$. Seven months after initial presentation he was readmitted for investigation. He was asymptomatic and had continued to gain weight; this, at $42.5 \mathrm{~kg}$, was now on the 75 th centile. Serum iron, vitamin B12, folate normal. Red cell folate $142 \mathrm{~g} / \mathrm{l}$ (low $\dagger$ ). Stool negative for culture and parasites. Barium meal and followthrough, normal. Small intestinal biopsy, normal, lymphocytes $34 / 100$ epithelial cells. He had continued well when last seen, 8 months after initial presentation.

\section{Discussion}

The initial presentation in these children was similar to that of acute gastroenteritis, although there was no contact history and no significant aetiological agent was found. In Case 1, scanty cysts of Giardia in one stool specimen was not confirmed at repeated examinations of stool and duodenal juice; $E$. coli $\mathrm{O} 55$, also found in the stool on one occasion out of many examinations in this patient, does not cause diarrhoeal illness at this age (Ironside, 1972). Thus neither of these agents was regarded as a significant pathogen.

The protracted diarrhoea and severe weight loss in all 3 children suggested the possibility of the acute onset of Crohn's disease. In retrospect this was an unlikely diagnosis in Cases 1 and 2 because of the absence of abdominal pain, and the diagnosis later became improbable with the spontaneous and uninterrupted resolution of symptoms in all 3 
children, and of the ileal abnormality in Cases 2 and 3. Infection with Yersinia was considered but neither the radiological nor biopsy findings were typical of such an infection (Vantrappen et al., 1977).

An enteropathy of variable severity occurs in acute gastroenteritis but is usually transient (Barnes and Townley, 1973; Schreiber et al., 1973). Persistent enteropathy has been described in the postgastroenteritis syndrome (Gribbin et al., 1976), but in the UK this has been described only in infancy. In Case 2 there was a marked, but transient, IgM deficiency and it is possible that an older child with some immunological disorder would react to an acute attack of gastroenteritis in an abnormal manner.

The illness in these children showed some features similar to the postinfective illness seen in adults returning from the tropics (Tomkins et al., 1974), in particular there was a severe enteropathy and low folate levels. In Case 1, Klebsiella was isolated from the duodenal juice and this organism may play a role in the pathophysiology of protracted diarrhoea in such adult patients (Klipstein et al., 1973).

Although there was evidence of acute inflammatory disease on proximal small intestinal biopsy in all three children and on rectal biopsy in Case 2, as well as radiological abnormality of the terminal ileum in cases 2 and 3, the final diagnosis remains uncertain.

We suggest that these three children suffered from the same disease, the precise nature of which remains to be clarified. It is possible that the disease represents either an infection by an, as yet, unidentified micro-organism or a postinfective enteritis. Perhaps the most important feature is the spontaneous resolution which occurred making the diagnosis of chronic inflammatory bowel disease improbable. It is hoped that this report will alert physicians to similar cases which they may encounter and that active treatment (for example corticosteroids, antibiotics) be withheld until there has been adequate investigation and observation.

We thank Dr Jean Dolby, Dr Norman France, Mr Alan Phillips, and Mrs Joanna Sacks for help in investigating these patients. P.M. is supported by the Queen Elizabeth Hospital Research Appeal Trust.

\section{References}

Barnes, G. L., and Townley, R. R. W. (1973). Duodenal mucosal damage in 31 infants with gastroenteritis. Archives of Disease in Childhood, 48, 343-349.

Gribbin, M., Walker-Smith, J. A., and Wood, C. B. S. (1976). Delayed recovery following acute gastroenteritis. Acta paediatrica Belgica, 29, 167-176.

Ironside, A. G. (1972). Gastroenteritis of infancy. Medicine, 6, 467-474.

Klipstein, F. A., Holdeman, L. V., Corcino, J. J., and Moore, W. E. C. (1973). Enterotoxigenic intestinal bacteria in tropical sprue. Annals of Internal Medicine, 79, 632-641.

Schreiber, D. S., Blacklow, N. R., and Trier, J. S. (1973). The mucosal lesion of the proximal small intestine in acute infectious nonbacterial gastroenteritis. New England Journal of Medicine, 288, 1318-1323.

Tomkins, A. M., James, W. P. T., Walters, J. H., and Cole, A. C. E. (1974). Malabsorption in overland travellers to India. British Medical Journal, 3, 380-384.

Vantrappen, C., Agg, H. O., Ponette, E., Geboes, K., and Bertrand, P. (1977). Yersinia enteritis and enterocolitis: gastroenterological aspects. Gastroenterology, 72, 220-227.

Correspondence to Dr P. D. Manuel, Queen Elizabeth Hospital for Children, Hackney Road, London E2 8PS. 